University of Nebraska - Lincoln

DigitalCommons@University of Nebraska - Lincoln

USDA National Wildlife Research Center - Staff Publications
U.S. Department of Agriculture: Animal and Plant Health Inspection Service

May 1983

\title{
SURVIVAL ANALYSIS FOR A RED SQUIRREL POPULATION
}

Curtis H. Halvorson

Denver Wildlife Research Center, U.S. Fish and Wildlife Service

Richard M. Engeman

Denver Wildlife Research Center, U.S. Fish and Wildlife Service, s_r100@yahoo.com

Follow this and additional works at: https://digitalcommons.unl.edu/icwdm_usdanwrc

Part of the Environmental Sciences Commons

Halvorson, Curtis H. and Engeman, Richard M., "SURVIVAL ANALYSIS FOR A RED SQUIRREL POPULATION" (1983). USDA National Wildlife Research Center - Staff Publications. 185.

https://digitalcommons.unl.edu/icwdm_usdanwrc/185

This Article is brought to you for free and open access by the U.S. Department of Agriculture: Animal and Plant Health Inspection Service at DigitalCommons@University of Nebraska - Lincoln. It has been accepted for inclusion in USDA National Wildlife Research Center - Staff Publications by an authorized administrator of DigitalCommons@University of Nebraska - Lincoln. 
Shult, M. J. 1972. American bison behavior patterns at Wind Cave National Park. Unpubl. Ph.D. dissert., Iowa State Univ., Ames, 178 pp.

SOPER, J. D. 1941. History, range and home life of the northern bison. Ecol. Monogr., 11:347-412.
VAN Vuren, D. 1979. Ecology and behavior of bison in the Henry Mountains, Utah. Unpubl. M.S. thesis, Oregon State Univ., Corvallis, 39 pp.

Dirk Van Vuren, Department of Fisheries and Wildlife, Oregon State University, Corvallis, OR 97331 (present address: Department of Systematics and Ecology, University of Kansas, Lawrence, KS 66045). Submitted 12 February 1982. Accepted 18 October 1982.

\section{SKULL FRAGMENTS OF THE CALIFORNIA SEA LION (ZALOPHUS CALIFORNIANUS) IN STOMACH OF A WHITE SHARK (CARCHARODON CARCHARIAS)}

White sharks (Carcharodon carcharias) have been observed to prey upon elephant seals (Mirounga angustirostris), harbor seals (Phoca vitulina), and sea lions (species undetermined) near the Farallon Islands between 1970 and 1979 (Ainley et al., 1980. Fish. Bull., 78:941-945, 1981). Jordon and Everman (Bull. 47, United States National Museum, Part 1, p. 50, 1896) reported finding sea lion remains in the stomach of a white shark, but the species was not mentioned. Stomachs of white sharks taken near San Diego in 1978 contained sea lion remains (Raymond Keys, pers. comm.). Because the northern sea lion (Eumatopias jubatus) is not known to occur south of the California Channel Islands, the remains were assumed to be those of the California sea lion and were not preserved. This paper documents the first account of a white shark consuming a California sea lion (Zalophus californianus).

On 12 April 1980, a female white shark was landed by a commercial fishing vessel near Santa Catalina Island, California. The shark was caught in a drift gill net approximately 4.83 kilometers west of the west end of Catalina Island over a 100-fathom $(183-\mathrm{m})$ oceanic contour. A haul out used by California sea lions is situated near the west end of the island. The net, set out during the night, lay about parallel to the island and at a depth of $22.7 \mathrm{~m}$. The curvilinear length of the shark was $502.95 \mathrm{~cm}$.

The remains of the sea lion in the stomach of the shark were all partially eroded skull fragments. They consisted of a complete mandible, including all teeth except the incisors, and the left frontal portion of the maxilla, which contained a canine and four post canines. Dr. Donald Patten (Los Angeles County Museum) determined that they were those of a California sea lion. Three measurements of the left half of the mandible were compared with those of 23 skulls of California sea lions from the Los Angeles County Museum and the Santa Barbara Natural History Museum. Comparisons indicate that the ingested specimen was probably an adult or subadult male.

I thank D. Patten, C. Woodhouse, D. Nelson, R. Johnson, and R. Keys for their information and advice in preparing this article. I thank Robbie Barker, skipper of the "Pacific Fin," for his description of how the white shark was caught.

John P. Scholl, Department of Fish and Game, 350 Golden Shore, Long Beach, CA 90802. Submitted 4 March 1982. Accepted 7 August 1982.

J. Mamm., 64(2):332-336, 1983

\section{SURVIVAL ANALYSIS FOR A RED SQUIRREL POPULATION}

A 13-year study of an isolated red squirrel (Tamiasciurus hudsonicus) population in Montana has provided the data necessary to analyze their survival. Such long-term, intensive studies of wild populations are rare. When reported, derived (ratio) estimates are used to develop survival information as Gross et al. (1974), and Keith and Windberg (1978) did in respective 9- and 15-year lagomorph studies. A more accurate method, following cohorts, was used by Armitage and Downhower (1974) and Mosby (1969), who presented results for six or more year-classes of sciurids in actuarial tables (Deevey, 1947; Allee et al., 1949).

No long-term red squirrel survival studies have been conducted, although Davis and Sealander (1971) estimated survival rates to 9 years from the age structures of killed samples. Ages were primarily estimated 

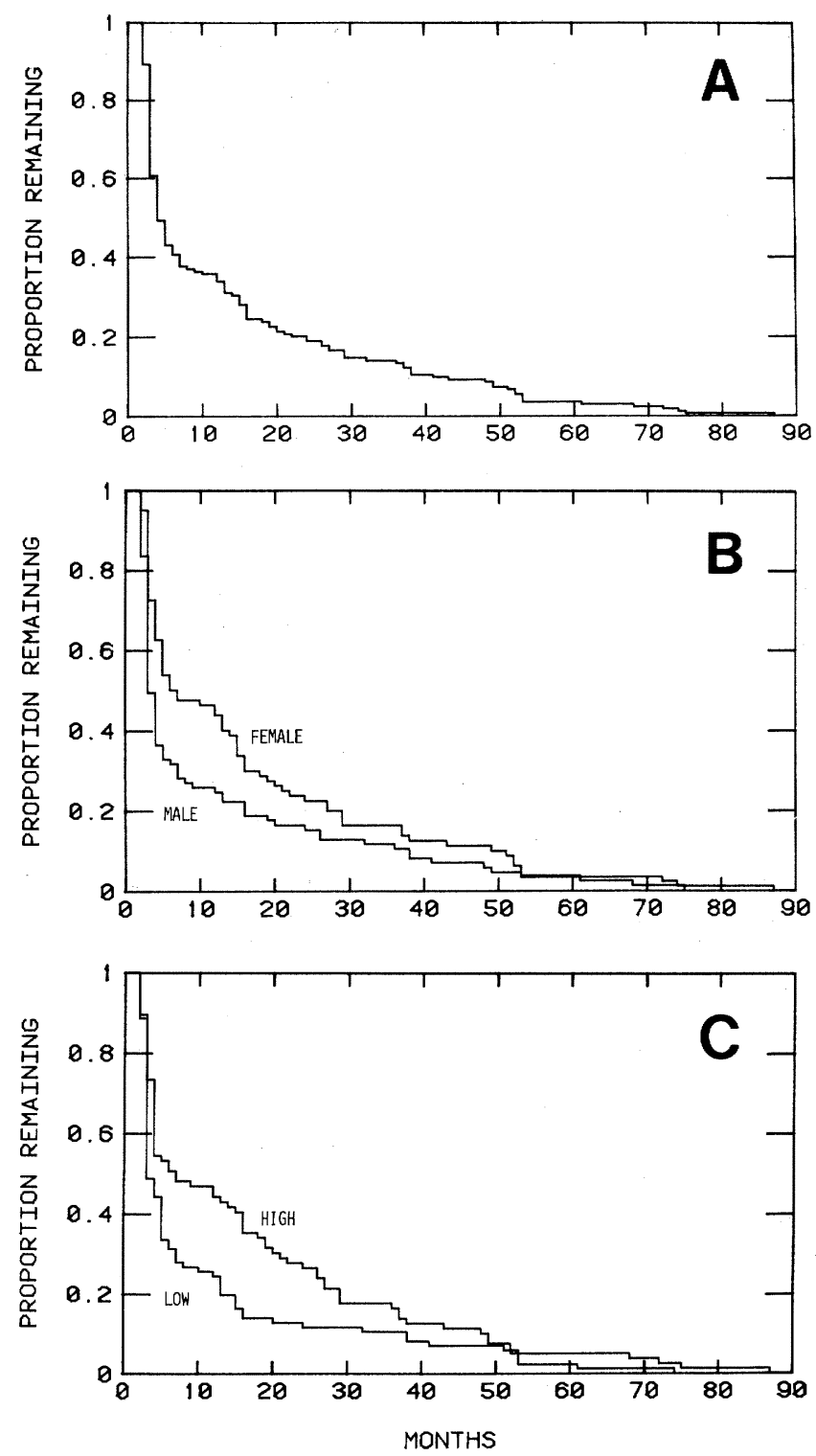

FIG. 1.-Product-limit survival curves plotting age versus the proportion of the population living to that age for (a) the overall squirrel population, (b) males versus females, (c) squirrels born in a high seed crop year versus those born in a low seed crop year.

using eye lens weights from known-aged, captive-reared squirrels. Davis and Sealander (1971) described their assumptions and the biases contained in their extrapolations beyond 36 months. Kemp and Keith (1970: 768) show survivorship rates for five age classes of red squirrels, using pooled age ratios, adult lens weights, and several assumptions. Friend (1968) critically reviewed the eye lens technique. Lemnell (1974) compared four laboratory methods for aging the European red squirrel (Sciurus vulgaris). He found the eye lens method was third in accuracy and judged it was best utilized simply to separate adults from juveniles. We present survival analysis for data spanning nine year-classes of red squirrels, analyzed by the product-limit method (Kaplan and Meier, 1958). 
TABLE 1.-The median longevity in months for each group of red squirrels of all ages and those that survived at least 1 year, the maximum longevity for each group and the P-values from the Mantel-Cox text for comparing survival curves.

\begin{tabular}{|c|c|c|c|c|c|c|c|}
\hline \multirow[b]{2}{*}{ Comparison } & \multirow[b]{2}{*}{ Group } & \multicolumn{2}{|c|}{ All ages } & \multicolumn{2}{|c|}{$\geq 1$ year survival } & \multirow{2}{*}{$\begin{array}{l}\text { Maximum } \\
\text { longevity }\end{array}$} & \multirow{2}{*}{$\begin{array}{c}\text { Mantel-Cox } \\
P \text {-value }\end{array}$} \\
\hline & & $\mathrm{N}$ & median & $\mathrm{N}$ & median & & \\
\hline Sex & $\begin{array}{l}\text { male } \\
\text { female }\end{array}$ & $\begin{array}{l}85 \\
80\end{array}$ & $\begin{array}{l}3 \\
6\end{array}$ & $\begin{array}{l}22 \\
37\end{array}$ & $\begin{array}{l}28 \\
24\end{array}$ & $\begin{array}{l}87 \\
75\end{array}$ & 0.05 \\
\hline $\begin{array}{l}\text { Seed crop level } \\
\text { in year of birth }\end{array}$ & $\begin{array}{l}\text { low } \\
\text { high }\end{array}$ & $\begin{array}{l}86 \\
79\end{array}$ & $\begin{array}{l}3 \\
7\end{array}$ & $\begin{array}{l}22 \\
37\end{array}$ & $\begin{array}{l}22 \\
27\end{array}$ & $\begin{array}{l}74 \\
87\end{array}$ & 0.02 \\
\hline Totals & & 165 & 4 & 59 & 26 & 87 & \\
\hline
\end{tabular}

The research was conducted on Cedar Island in Flathead Lake, Montana $\left(47^{\circ} 50^{\prime} \mathrm{N}, 114^{\circ} 2^{\prime} \mathrm{W}\right)$. The island was uninhabited, forested, and $450 \mathrm{~m}$ from the mainland and $220 \mathrm{~m}$ from a similar-sized island. The size (9.6 ha) and location of the island provided an accessible, but isolated, population of red squirrels that could be studied intensively with a minimum of exchange with other squirrel populations. Predators identified on Cedar Island were those also common to the mainland. They included two mustelids (Mustela erminea, $M$. vison), coyote (Canis latrans), great horned owl (Bubo virginianus), goshawk (Accipiter gentilis), and Cooper's hawk (A. cooperii). There was no reason to believe predator pressure differed from that on the mainland. Squirrel remains were found in pellets and scat.

The data for our study were collected from cohorts of red squirrels (193 animals) from fall 1959 to spring 1973 by one of us $(\mathrm{CHH})$. This period encompassed various combinations of high and low squirrel production and survival, as well as varying conifer seed crop levels (Pinus ponderosa, Pseudotsuga menziesii).

Squirrels on the island were censused using live traps and sightings. Time-specific population data were obtained from 1,800 handlings (Halvorson, 1972) and 1,200 sightings of color-tagged individuals. The traps were opened at 31 fixed locations (most near squirrel middens) for 3 or 4 days per month in April, July, August, September, and November. Additional trapping was used to capture and mark juveniles as they came out of the maternal nests. All squirrels used in our analyses $(n=165)$ were first handled as juveniles or subadults (criteria as set by Hanson, 1963).

Each animal was followed until its loss (disappearance) from the Cedar Island population was confirmed. The data from 28 of the 193 squirrels were censored (10 still alive when the study ended and 18 that changed locations from or to the adjacent island where squirrels were also monitored). Disappearance of noncensored squirrels from the Cedar Island population was assumed due to mortality but seldom could be confirmed. We conservatively defined squirrel survivorship as the length of time a native Cedar Island squirrel could be trapped or sighted on the island. Animals considered lost had their loss dates estimated as the midpoints in time between the last live records and the first trap periods in which they did not appear. The midpoint of the longest (over winter) interval was 2.5 months. The data follow Deevey's (1947) most rigid data requirement, that of closely-followed cohorts during their existence.

Survival information was calculated from the time the young were first vulnerable to traps, which occurred at weaning ( 7 to 8 weeks of age). Thus, longevity (months) was calculated as the survival time after weaning plus 2 months. Loss between birth and weaning was not measured.

We analyzed the data by the product-limit life table method (Kaplan and Meier, 1958; Gross and Clark, 1975), which estimates the survival distribution of the population under consideration. Actuarial life table analyses (Cutler and Ederer, 1958; Gross and Clark, 1975) are less appropriate for the purpose of examining these survival distributions because they estimate the conditional probability that an individual will survive through a time interval, given that it entered that interval. Thus, results of an actuarial life table analysis are dependent on the choice of the time intervals, whereas the product-limit method is independent of time intervals. The product-limit method more accurately presents what we wished to examine and is not prone to biases through the selection of time intervals.

We developed survival curves (Fig. 1) for (1) all squirrels combined, (2) males versus females, and (3) squirrels born in low versus high seed crop years. A high seed crop year was defined as one in which there were at least $5.6 \mathrm{~kg}$ seed/ha. Survival curves were compared using the Mantel-Cox test (Mantel, 1966). The 28 squirrels with censored data were omitted from the analyses to avoid possible bias problems in the results (Gross and Clark, 1975).

Our data for the overall population (Fig. la) show a survival pattern in which most loss (about 67\%) occurs before 12 months. A plateau occurs at about 36 months, and very few squirrels survive past 7 years. 
It was of much interest to us that the data of Davis and Sealander (1971:306-307) and Kemp and Keith (1970:767-768) show general correspondence for the 0-12-month and >36-month age classes, with a similar trend intervening, despite substantial differences in the precision and analytical treatment of their data. High initial loss, followed by a gradual extension into a residual old-age class, has been described for other sciurids (Mosby, 1969; Beg, 1971; Tryon and Snyder, 1973; Armitage and Downhower, 1974). The red fox (Storm, 1972) is one example of a medium-sized mammal following this curve.

The survival curves for male and female squirrels (Fig. 1b) were significantly different (Mantel-Cox test, $\chi^{2}$ d.f.1 $\left.=3.753, P=0.05\right)$. The median longevity for males was 3 months, whereas that for females was 6 months (Wilcoxon rank sum test, $\mathrm{W}=7601.5, \mathrm{~N} 1=85, \mathrm{~N} 2=80, P=0.002$ ). This may be a species survival adaptation whereby the females are more likely to reach breeding age than males. However, of the squirrels that lived at least 1 year, the median longevity for males was greater than that for females, 28 months versus 24 months (Table 1). Of the squirrels that reach 1 year of age, the males, perhaps not being subject to the stresses of raising a litter (Smith, 1968), lived as long or longer than the females, albeit their longevity was not significantly greater.

The survival curves for squirrels born in high and low seed crop years (Fig. lc) were also significantly different (Mantel-Cox, $\chi^{2}$ d.f.1 $=5.514, P=0.02$ ). The median longevity for squirrels born in a low seed crop year was 3 months; that for squirrels born in a high seed crop year was 7 months (Wilcoxon rank sum test, $\mathrm{W}=7375.5, \mathrm{~N} 1=86, \mathrm{~N} 2=79, P=0.008$ ). The greater longevity of squirrels born in a high seed crop year is also evident in the squirrels that survived at least 1 year (Table 1). The median longevity for those squirrels surviving 1 year that were born in a low seed crop year was 22 months, whereas the median longevity for those squirrels born in a high seed crop year was 27 months, although these medians are not significantly different. The implication from these results is that a squirrel born in a high seed crop year may have a survival advantage, at least in the short term.

In a critical review of published mortality rates for several taxa, Caughley (1966) discussed a common characteristic shared by members of orders as different as rodents and ungulates-high juvenile mortality followed by a low but gradually increasing mortality rate. Our data closely approximate the pattern which Caughley (1966) delineated, and was first described by Pearl as a Type III curve (Krebs, 1972:158). Our findings complement this commonality of loss (survival) rates, relative to age classes, among diverse species of mammals, and portray red squirrel survival in new detail.

We thank Dr. Guy N. Cameron and Dr. John A. Wrazen and anonymous reviewers for their helpful comments.

\section{Literature Cited}

Allee, W. C. Et Al. 1949. Principles of animal ecology. W. B. Saunders Co., Philadelphia, 837 pp.

Armitage, K. B., and J. F. Downhower. 1974. Demography of yellow-bellied marmot populations. Ecology, 55:1233-1245.

BEG, M. 1971. Population dynamics of the redtailed chipmunk, (Eutamias ruficaudus), in western Montana. Pakistan J. Zool., 3:133-145.

Caughley, G. 1966. Mortality patterns in mammals. Ecology, 47:906-918.

Cutler, S. J., ANd F. Ederer. 1958. Maximum utilization of the life table method in analyzing survival. J. Chronic Dis., 8:699-713.

Davis, D. W., and J. A. Sealander. 1971. Sex ratio and age structure in two red squirrel populations in northern Saskatchewan. Canadian Field-Nat., 85:303-308.

Deevey, E. S., JR. 1947. Life tables for natural populations of animals. Quart. Rev. Biol., 22:283314.

Friend, M. 1968. The lens technique. Trans. N. Amer. Wildl. Conf., 33:279-298.

Gross, A. J., AND V. A. Clark. 1975. Survival distributions: reliability applications in the biomedical sciences. Wiley, New York, 331 pp.
Gross, J. E., L. C. Stoddart, and F. H. Wagner. 1974. Demographic analysis of a northern Utah jackrabbit population. Wildl. Monogr., 40:1-68.

Halvorson, C. H. 1972. Device and technique for handling red squirrels. Spec. Sci. Rept., U.S. Fish Wildl. Serv., Washington, 159:1-10.

Hanson, W. R. 1963. Calculation of productivity, survival, and abundance of selected vertebrates from sex and age ratios. Wildl. Monogr., 9:1-60.

Kaplan, E. L., and P. MEIER. 1958. Nonparametric estimation from incomplete observations. J. Amer. Stat. Assoc., 53:457-481.

KeITH, L. B., AND L. A. Windberg. 1978. A demographic analysis of the snowshoe hare cycle. Wildl. Monogr., 58:1-70.

Kemp, G. A., AND L. B. Keith. 1970. Dynamics and regulation of red squirrel (Tamiasciurus hudsonicus) populations. Ecology, 51:763-779.

KrebS, C. J. 1972. Ecology. Harper and Row, New York, $694 \mathrm{pp}$.

Lemnell, P. A. 1974. Age determination in red squirrels, (Sciurus vulgaris). Internat. Congr. Game Biol., Stockholm, 11:573-580.

Mantel, N. 1966. Evaluation of survival data and two new rank order statistics arising in its consideration. Cancer Chemotherapy Repts., 50:163-170. 
Mossy, H. S. 1969. The influence of hunting on the population dynamics of a woodlot gray squirrel population. J. Wildl. Mgmt., 33:59-73.

SMITH, C. C. 1968. The adaptive nature of social organization in the genus of tree squirrels, Tamiasciurus. Ecol. Monogr., 38:31-63.

Storm, G. L. 1972. Population dynamics of red foxes in north central United States. Unpubl. Ph.D. dissert., Univ. Minnesota, St. Paul, 226 pp.

Tryon, C. A., And D. P. SNyder. 1973. Biology of the eastern chipmunk, Tamias striatus: life tables, age distribution, and trends in population numbers. J. Mamm., 54:145-168.

Curtis H. Halvorson and Richard M. Engeman, Denver Wildlife Research Center, U.S. Fish and Wildlife Service, 1300 Blue Spruce Drive, Ft. Collins, CO 80524, and Bldg. 16, Denver Federal Center, Denver, CO 80225. Submitted 22 January 1982. Accepted 18 August 1982.

\section{RESPONSE OF PIKAS TO PLAYBACK OF GEOGRAPHIC VARIATIONS OF THE SHORT CALL}

Significant quantitative differences have been detected in fundamental frequency and note duration of short calls of pikas (Ochotona princeps) from populations north and south of the Colorado River in the Rocky Mountains (Somers, 1973) and among populations in the Sierra Nevada of California, the Wasatch Range of Utah, and the Sangre de Cristo Mountains of New Mexico (Conner, 1982). In both studies, vocal responses to playback of short calls were measured to ascertain whether pikas discriminate between calls from their own population and those from "foreign" populations. The number of vocal responses to playback of their own population's call did not differ significantly from playback of calls from other populations or from control periods of silence during which no calls were played. These results suggest only that the playback of short calls does not stimulate calling in pikas as it does in many avian species (Catchpole, 1979); they suggest nothing about a pika's ability to discriminate between short calls from differ int populations. Another measure of responsiveness is needed if the ability of pikas to discriminate between structurally different calls is to be rigorously tested.

The usual response of a pika to a neighbor's short call is to stop what it is doing, look towards the caller, and resume its activity if no other stimuli (predator, territorial intruder) are present (Somers, 1973; Conner, 1979). These observations suggest that some measure of attention or orientation can be used to determine playback discrimination.

Twenty-one wild pikas from a population in New Mexico $\left(35^{\circ} 37^{\prime} 42^{\prime \prime} \mathrm{N}, 105^{\circ} 47^{\prime} 11^{\prime \prime} \mathrm{W}\right)$ were presented successively with the same set of paired short calls, one call recorded from their own population (not their own call, but one with which they were presumably familiar) and one unfamiliar call recorded from a population in Utah $\left(37^{\circ} 36^{\prime} 5^{\prime \prime} \mathrm{N}, 112^{\circ} 49^{\prime} 7^{\prime \prime} \mathrm{W}\right)$. Short calls were played through a Uher 4000 Report IC tape recorder placed at the edge of the talus and a $5^{\prime \prime}$ Radio Shack speaker placed within the talus. Playbacks were presented between 0700 and $1000 \mathrm{~h}$ on 21 and 22 September 1978. The successive presentation of short calls was separated by two minutes of silence and the order of presentation was changed after each individual was tested. An individual was considered as "attending to the call" if it stopped its activity and looked towards the speaker, changed position to face the speaker, or moved towards it. The degree of attention was measured as the time spent in the new activity. Of 21 individuals tested, 19 (90\%) responded to a call from their own population with a mean response duration of $15.2 \mathrm{~s}(\mathrm{SD}=7.4 \mathrm{~s})$. Only 8 (38\%) New Mexican pikas responded to the call of the Utah population with a mean response duration of $2.9 \mathrm{~s}$ $(\mathrm{SD}=1.4 \mathrm{~s})$. A significantly larger proportion of animals responded to a call from its own population $\left(t_{\mathrm{s}}=\right.$ $3.84, P<0.001$; Sokal and Rohlf, 1969, p. 607) with a significantly longer mean response duration (MannWhitney one-tailed test with tied ranks; $U=149.5, P<0.001$ ). This playback series shows that a behavioral response by pikas exists which can be used to measure discrimination of playback of different vocalizations.

The present results demonstrate that pikas are able to discriminate between different geographic forms of the short call, but why pikas discriminate between local and strange forms of the call is not clear. It is unlikely that the ability to discriminate differences in call structure plays a role in assortative mating that reduces gene flow among populations (Baker and Newaldt, 1978), or in preventing individuals from mating with close relatives (Jenkins, 1978), as has been suggested for avian song discrimination (Krebs and Kroods$\mathrm{ma}, 1980$ ). The pikas' habitat specificity, temperature limitations, and risk of predation while off the talus (Smith, 1981) serve as effective barriers to interbreeding except for populations living very close to one 